\title{
Role of Aspergillus flavus on Biodegradation of Lignocellulosic Waste Millet Straw and Optimization Parameters for Enzyme Hydrolysis and Ethanol Production under Solid State Fermentation
}

\author{
Prathvi V. Narsale, Sejal R. Patel ${ }^{*}$ and Pradeep Acharya
}

M. D. Gram Seva Mahavidyalaya, Gujarat Vidyapeeth, Sadra, Gandhinagar, India

*Corresponding author

Keywords

Lignocellulosics waste, Millet straw, Cellulase, Aspergillus flavus, CMC agar medium, Solid state fermentation,

Endoglucanase

Saccharification,

Saccharomyces cerevisiae

Article Info

Accepted:

08 January 2018

Available Online:

10 February 2018

\section{A B S T R A C T}

Amongst six natural lignocellulosic waste/raw material screened, millet straw contained maximum cellulose $(30 \%)$ and physical and chemical pre-treatment yielded maximum cellulase activity. The composition of millet straw showed $30 \%$ cellulose, $10 \%$ hemicellulose, $8.73 \%$ total organic carbon, $0.7 \%$ total nitrogen and $0.8 \mathrm{ppm}$ phosphorous. Amongst four fungi of genus Aspergillus isolated from local soil dumps of kitchen and garden waste, Aspergillus flavus showed maximum cellulase activity on CMC agar medium and used for degradation of millet straw. Amongst five media, Mandle and Sternberg fermentation medium showed maximum enzyme activity due to favorable $\mathrm{pH}$ and supplementing nitrogen and mineral requirements for growth and development of Aspergillus flavus. The optimum parameters for maximum cellulolytic enzyme activity in solid state fermentation were also studied which showed that $1 \mathrm{ml}$ inoculum size, $4.5 \mathrm{pH}$ of the medium, incubation at $28{ }^{\circ} \mathrm{C}$ and $70 \%$ moisture content for $120 \mathrm{~h}, 3.0 \% \mathrm{w} / \mathrm{v}$ substrate concentration, $0.1 \%$ supplementation of carbon source in form of Carboxy Methyl Cellulose and $0.5 \%$ of nitrogen source in form of ammonium sulphate found effective for better endoglucanase activity. The hydrolysate was subjected to saccharification (fermentation through yeasts Saccharomyces cerevisiae) having potential of producing $0.15 \mathrm{~g} /$ hour/liter of ethanol at above optimized parameters.

\section{Introduction}

Besides growing demand of lignocellulosic materials for traditional applications (paper manufacture, biomass fuels, composting, animal feed, etc.), novel markets for conversion of lignocellulose to alternative energy carriers (e.g. bioethanol, acetone and butanol) are also well recognized (Kaylen et al., 2000; Lee, 1997; Mitchell, 1998; Wheals et al., 1999). Cellulose, hemicellulose and lignin are the main constituents of lignocellulosic materials (Deobald and Crawford, 1997). Agricultural resources of lignocellulosic waste are quite abundant as estimated by the Food and Agriculture Organization (FAO), USA. Around $2.9 £ 103$ million tons from cereal crops and $1.6 £ 102$ million tons from pulse crops, $1.4 £ 10$ million tons from oil seed crops and5.4 $£ 102$ million tons from plantation crops are produced annually worldwide (Rajaram and Verma, 
1990).The chemical composition of native agricultural waste obtained from plants differs considerably and is influenced by genetic and environmental factors. Amongst various types of natural lignocellulosic raw materials having varying amounts of cellulosic components; lignocellulose is a complex substrate and its biodegradation is not dependent on environmental conditions alone, but also the degradative capacity of the microbial population (Waldrop et al., 2000). Most fungi are capable cellulose degraders. However, their ability to facilitate rapid lignocellulose degradation attracted attention from scientists and entrepreneurs alike. Therefore, the bioconversion of large amounts of lignocellulosic biomass into fermentable sugars has potential application in the area of bio-energy generation. Easy, cheap and abundant lignocellulosic raw materials having high cellulose content and resultant/ultimate high enzyme bio-synthesis has potential in bioconversion of cellulose into fermentable sugars and is abio-refining area that has invested enormous research efforts, as it is a prerequisite for the subsequent production of bio-energy. Sugars and starch comprise the feedstock for $90 \%$ of the produced ethanol today, but the most prevalent forms of sugar in nature are cellulose and hemicellulose. Lignocellulosic biomass can be converted to ethanol by hydrolysis and downstream fermentation processing. This processis much more complicated than just fermentation of $\mathrm{C}_{6}$ sugar (De Ruyck et al., 1996) and is still far from being cost effective as compared to the production of bioethanol from starch or sugar crops. In hydrolysis, the cellulosic part of the biomass is converted into sugars, and fermentation converts these sugars to ethanol. Lignocellulosic biomass consists of 1025\%lignin, which contains no sugar and therefore impossible to convert into sugars. Lignin is therefore a residue in ethanol production and it represents a big challenge to convert it into a value-added product.
However, attempt was made to screen lignocellulosic raw material such as wheat straw and leaf litter, millet straw, mustard straw, rice husk and cotton seed cake abundant in the region with high cellulose content with potential strain of local/ native cellulose degrading fungi for cellulolytic enzyme biosynthesis in ideal fermenting medium for sugar and ethanol production in optimized condition.

\section{Materials and Methods}

\section{Substrate selection and physico-chemical composition}

Commonly available lignocellulosic waste/raw material viz., cotton seed cake, rice husk, millet straw, mustard straw, wheat straw and leaf litter were collected from the local farms near Sadra village; district Gandhinagar, Gujarat and each substrate were subjected to physical-chemical pretreatment for delignification and breaking down the macro and micro fibrils, increasing the surface area for better penetration of fungi. These lignocellulosic waste materials were subjected to mechanical grinding and sieving to finer particles of $3 \mathrm{~mm}$ size. Ten gram of substrate was soaked in 1 to $5 \mathrm{~N}$ of $\mathrm{NaOH}$ for $24 \mathrm{~h}$ and washed repeatedly with distilled water till neutral $\mathrm{pH}$ and kept overnight at $60^{\circ} \mathrm{C}$ for drying.

\section{Physico-chemical properties of substrate}

The amount of cellulose was estimated by colorimetric method (Thimmaiah, 2006) by mixing dry sample with Acetic/nitric reagent, $67 \% \mathrm{H}_{2} \mathrm{SO}_{4}$ and finally allowed to react with chilled Anthrone reagent. Amount of cellulose was estimated from standard curve using standard cellulose solution.

The amount of hemicellulose was determined colorimetric method (Thimmaiah, 2006). The 
sample was refluxed using cold Neutral detergent fiber by adding $2.0 \mathrm{ml}$ of decahydronapthalene and $0.5 \mathrm{~g}$ sodium sulphite in boiling water bath for $60 \mathrm{~min}$. After drying at $100^{\circ} \mathrm{C}$ for $8 \mathrm{~h}$ crucible was cooled in desiccators and weighed. The amount of hemicelluloses was obtained by subtracting Acid detergent fiber from Neutral detergent fiber.

Total organic carbon was evaluated by titration method (Walkley and Black, 1934). The method is based on the oxidation of organic matter by potassium dichromate $\left(\mathrm{K}_{2} \mathrm{Cr}_{2} \mathrm{O}_{7}\right)$-sulfuric acid mixture followed by back titration of the excessive dichromate by standard ferrous ammonium sulfate $\left[\mathrm{Fe}\left(\mathrm{NH}_{4}\right)_{2}\left(\mathrm{SO}_{4}\right)_{2} \cdot 6 \mathrm{H}_{2} \mathrm{O}\right]$ in the presence of $\mathrm{NaF}$ or phosphoric acid and diphenylamine indicator.

For total nitrogen estimation, digestion method (Snell and Snell, 1954) was used. Plant sample was digested with concentrated $\mathrm{H}_{2} \mathrm{SO}_{4}$ and then with $\mathrm{H}_{2} \mathrm{O}_{2}$ till it became colorless. The intensity of colour developed by Nessler's reagent in the presence of $\mathrm{NaOH}$ and sodium silicate was measured on a spectrophotometer at $440 \mathrm{~nm}$ wavelength by using blue filter. The nitrogen content (ppm) was calculated with the help of standard curve.

Total phosphorus in plant sample was determined by vanadomolybdo phosphoric yellow colour method (Jackson, 1973). Orthophosphates obtained in triacid digest react with ammonium molybdate ammonium vanadate in $\mathrm{HNO}_{3}$ medium and gives a yellow colour complex.

The colour developed in about 30 minutes and remained stable for 2 to 8 weeks. Intensity of colour was measured at $470 \mathrm{~nm}$ wavelength in a Spectrophotometer. The ppm content of phosphorus was obtained with the help of standard curve.
Microorganism selection and Inoculum Preparation

Amongst four fungi of genus Aspergillus isolated from local soil dumps of kitchen and garden waste was grown on Carboxy Methyl Cellulose (CMC) agar medium and the culture was selected on the basis of higher cellulase activity and pure culture was identified based on morphology and colony characteristics.

The selected culture was grown on PDA slants for further use as inoculum preparation.

\section{Medium selection and composition}

The growth medium used in solid state fermentation (SSF) process required supplementation of additional nutrients to stimulate growth and enhance enzyme synthesis.

Five different media viz., Mineral Salt [Composition g/l: Peptone protease1.0g, $\left(\mathrm{NH}_{4}\right)_{2} \mathrm{SO}_{4} 1.4 \mathrm{~g}, \mathrm{KH}_{2} \mathrm{PO}_{4} 2.0 \mathrm{~g}$, Urea $0.3 \mathrm{~g}$, $\mathrm{CaCl}_{2} 0.3 \mathrm{~g}, \quad \mathrm{MgCl}_{2} .7 \mathrm{H}_{2} \mathrm{O} 0.3 \mathrm{~g}, \quad \mathrm{FeSO}_{4} .7 \mathrm{H}_{2} \mathrm{O}$ $0.005 \mathrm{~g}, \mathrm{MnSO}_{4} . \mathrm{H}_{2} 00.06 \mathrm{~g}, \mathrm{ZnSO}_{4} .7 \mathrm{H}_{2} 00.4 \mathrm{~g}$ at pH-5.0], Mandles and Sternberg [Composition g/l: Urea $0.3 \mathrm{~g},\left(\mathrm{NH}_{4}\right)_{2} \mathrm{SO}_{4} 1.4$ g, $\mathrm{KH}_{2} \mathrm{PO}_{4} 2.0 \mathrm{~g}, \mathrm{CaCl}_{2} 0.3 \mathrm{~g}, \mathrm{MgCl}_{2} .7 \mathrm{H}_{2} \mathrm{O}$ $0.3 \mathrm{~g}$, Protease peptone $1.0 \mathrm{mg}, \mathrm{FeSO}_{4} .7 \mathrm{H}_{2} \mathrm{O}$ $5.0 \mathrm{~g}, \mathrm{MnSO}_{4} .7 \mathrm{H}_{2} \mathrm{O} 1.6 \mathrm{~g}, \mathrm{ZnSO}_{4} .7 \mathrm{H}_{2} 01.4 \mathrm{~g}$, Tween-80 $0.1 \%(\mathrm{v} / \mathrm{v})$ at $\mathrm{pH}$ 5.2], Berg's medium [Composition g/l: $\mathrm{NaNO}_{3} \quad 0.5$ g, $\mathrm{MgSO}_{4} 0.05 \mathrm{~g}, \mathrm{FeSO}_{4} 0.01 \mathrm{~g}, \mathrm{CaCl}_{2} 0.02 \mathrm{~g}$, $\mathrm{MgSO}_{4} 0.02 \mathrm{~g}$ at $\mathrm{pH}$ 7.0], Czapek-dox medium [Composition g/l: Sucrose $30.0 \mathrm{~g}$, yeast extract $7.0 \mathrm{~g}, \mathrm{KH}_{2} \mathrm{PO}_{4} 2.0 \mathrm{~g}, \mathrm{NaNO}_{2} 8.0 \mathrm{~g}, \mathrm{KCl} 3.0 \mathrm{~g}$, $\mathrm{MgCl}_{2} .7 \mathrm{H}_{2} \mathrm{O} \quad 3.0 \mathrm{~g}, \quad \mathrm{FeSO}_{4} .7 \mathrm{H}_{2} \mathrm{O} \quad 2.0 \mathrm{~g}$, $\mathrm{ZnSO}_{4} .7 \mathrm{H}_{2} \mathrm{O} 2.0 \mathrm{~g}, \mathrm{CuSO}_{4} 0.08 \mathrm{~g}$ at $\left.\mathrm{pH} 4.8\right]$ and Waber and Mandles [Composition g/l:

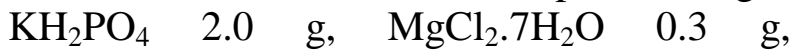
$\mathrm{CaCl}_{2} \cdot 2 \mathrm{H}_{2} \mathrm{O} 0.3 \mathrm{~g}, \mathrm{CoCl}_{2} 2.0 \mathrm{~g}, \mathrm{MnSO}_{4} \cdot \mathrm{H}_{2} \mathrm{O}$ $1.6 \mathrm{~g}, \mathrm{ZnSO}_{4} \cdot \mathrm{H}_{2} 05.0 \mathrm{~g}$, Tween-80 2.0\%(v/v) at $\mathrm{pH}$ 5.0] were evaluated for higher enzyme activity. 


\section{Optimization of parameters for enzymatic Hydrolysis}

Various parameters such as inoculation size, $\mathrm{pH}$ of fermentation medium, incubation temperature, incubation time, moisture content of the substrate, substrate concentrations and supplementation of carbon and nitrogen source etc., were studied to find out the best hydrolyzing conditions for millet straw using cellulose produced by Aspergillus flavus.

The optimum condition obtained from each experiment was used in the next optimization study unless otherwise stated.

\section{Inoculation size}

Fungi Aspergillus flavus was grown on PDA (Potato Dextrose Agar) slants and spores were harvested from 7 days old PDA slants. $10 \mathrm{ml}$ of sterile distilled water was added to these slants. Spore count was measured and adjusted to $10^{7}$ spores $/ \mathrm{ml}$ by adjustment of optical density. Three gram of pretreated millet straw was wetted with Mandles and Stenberg medium was loaded with different concentrations of inoculum $(0.5 \mathrm{ml}, 1.0 \mathrm{ml}$, $1.5 \mathrm{ml}, 2.0 \mathrm{ml}, 2.5 \mathrm{mland} 3.0 \mathrm{ml}$ ) and incubated at room temperature $\left(28^{\circ} \mathrm{C}\right)$ for 7 days.

\section{pH of the medium}

The $\mathrm{pH}$ of the medium was adjusted to $4.0,4.5$, $5.0,5.5,6.0,6.5$ and 7.0 by adding required amount of $1 \mathrm{~N} \mathrm{HCl}$ and $1 \mathrm{~N} \mathrm{NaOH} ; 1 \mathrm{ml}$ of inoculum was added and finally incubated at room temperature $\left(28^{\circ} \mathrm{C}\right)$ for 7 days.

\section{Incubation temperature}

Hydrolysis was performed at different temperatures $\left(23^{\circ} \mathrm{C}, 28^{\circ} \mathrm{C}, 37^{\circ} \mathrm{Cand} 50^{\circ} \mathrm{C}\right)$ to determine the optimum temperature by adding $1.0 \mathrm{ml}$ inoculum in the flask keeping $\mathrm{pH}$ of the medium as 4.5 and incubated for 7 days.

\section{Incubation time}

The enzymatic hydrolysis study was carried out for a period of $240 \mathrm{~h}$ by adding $1.0 \mathrm{ml}$ inoculum in the flask keeping $\mathrm{pH}$ of the medium as 4.5 and incubating at the temperature of $28^{\circ} \mathrm{C}$ and every $24 \mathrm{~h}$ interval enzymatic activity was measured. Maximum hydrolysis occurred at $120 \mathrm{~h}$ and was found to be decreased thereafter.

\section{Moisture content of substrate}

Moisture content was varied to $40 \%, 50 \%$, $60 \%, 70 \%$ to $80 \%$ for enzyme biosynthesis; flasks inoculated with $1.0 \mathrm{ml}$ inoculam, $\mathrm{pH} 4.5$ followed by $120 \mathrm{~h}$ incubation period at $28^{\circ} \mathrm{C}$.

\section{Substrate concentration}

The pretreated substrate at $70 \%$ moisture content was suspended in fixed volume (10 $\mathrm{ml})$ of buffer ( $\mathrm{pH} 4.5)$ with different weights $(1.0,3.0,5.0,7.0$ and $10.0 \mathrm{~g})$ and $1.0 \mathrm{ml}$ inoculum was added and incubated for 120 hat $28^{\circ} \mathrm{C}$.

\section{Supplementation of carbon and nitrogen source}

Mandles and Stenberg medium was contained $0.1 \%$ of different carbon sources like glucose, sucrose, CMC, xylose, wheat flour and cellobios; and $0.5 \%$ of different nitrogen sources like ammonium nitrate $\left(\mathrm{NH}_{4}\right)_{2} \mathrm{NO}_{3}$, ammonium sulfate $\left(\mathrm{NH}_{4}\right) \mathrm{SO}_{4}$, yeast extract, protease peptone and urea. The flasks inoculated with $1.0 \mathrm{ml}$ inoculum, $\mathrm{pH} 4.5$, moisture content $70 \%$, were now incubated at $28^{\circ} \mathrm{C}$ for $120 \mathrm{~h}$.

\section{Extraction of enzyme}

After incubation, $50.0 \mathrm{ml}$ of citrate buffer (0.1M, pH 4.5) was added to each fermented flasks and homogenized at 10,000 rpm in a 
rotator shaker for $30 \mathrm{~min}$ at room temperature to extract the product and extracted mixture was used to measure enzymatic activity and reducing sugars.

\section{Cellulase activity}

Carboxymethyl cellulase (CMCase) is mainly evaluated based on the procedure described by Mandels et al., (1976).In this method, CMCase activity is measured by determining reducing sugars released after $5 \mathrm{~min}$ of enzyme reaction with $1.0 \%$ Carboxy Methyl Cellulose at $\mathrm{pH} 4.8$ and $50^{\circ} \mathrm{C}$ (Mandels et al., 1976). Also, one unit (IU) of EG is defined as the amount of enzyme that liberates $1 \mu \mathrm{mol}$ of glucose per minute under assay. The amount of reducing sugars released was measured by colorimetric method using dinitro salicylic acid according to Miller's method (Miller, 1959) with glucose as standard. The activity was expressed in international unit (IU), defined as the amount of enzyme required to produce $1 \mu \mathrm{mol}$ glucose $/ \mathrm{min}$.

\section{Enzymatic hydrolysis at optimized condition}

Considering all above optimization parameters, enzymatic hydrolysis was performed and compared with the results of un-optimized conditions during experimentation.

\section{Enzymatic saccharification and bioethanol production}

\section{Inoculum preparation}

A culture suspension of Saccharomyces cerevisiae was prepared by adding $10 \mathrm{ml}$ sterile distilled water in Glucose Yeast Extract Agar slants containing yeast culture. Optimal density was measured at $600 \mathrm{~nm}$ against distilled water as blank. The optical density of inoculum was adjusted to 1.0 O.D. $\left(1 \times 10^{7}\right.$
$\mathrm{CFU} / \mathrm{ml}) .5 \% \mathrm{v} / \mathrm{v}$ of this inoculum taken for saccharification of fermented hydrolysate.

\section{Fermentation process}

The flasks containing $5 \mathrm{~g}$ of millet straw was wetted with Mandles and Sternberg medium, at $\mathrm{pH} 4.5$,with $70 \%$ moisture content; autoclaved at $121^{\circ} \mathrm{C}$ and $15 \mathrm{lbs}$; inoculated with $1.0 \mathrm{ml}$ Aspergillus flavus $\left(1 \times 10^{7}\right.$ spores $/ \mathrm{ml}$ ) and incubated at $28^{\circ} \mathrm{C}$ for $120 \mathrm{~h}$. After incubation $200 \mathrm{ml}$ of sterile distilled water was added to the fermentation flask; homogenized at $10,000 \mathrm{rpm}$ for $10 \mathrm{~min}$ on environment shaker; filtered; centrifuged at $10,000 \mathrm{rpm}$ for $10 \mathrm{~min}$ at $4^{\circ} \mathrm{C}$; autoclaved at 10 psi for 10 min and transferred in sterilized anaerobic glass bottle with $250 \mathrm{ml}$ capacity; inoculated with $5 \% \mathrm{v} / \mathrm{v}$ of Saccharomyces cerevisiae culture. Then, the anaerobic glass bottle was immediately stopped with the rubber stopper (sterilized by dipping it in boiled water for $10 \mathrm{~min}$, just before use) having a hole through which a sterilized plastic tube (sterilized same as rubber stopper) was inserted in to the bottle whose another end was dipped in a $150 \mathrm{ml}$ capacity conical flask containing $100 \mathrm{ml}$ of $3 \mathrm{~N} \mathrm{NaOH}$ to collect $\mathrm{CO}_{2}$ produced in bottle during fermentation process. The anaerobic glass bottle and $\mathrm{NaOH}$ containing flask was sealed by vaccum grease or parafilm tap and placed under stationary condition was done for 4 days. After 4 days, $\mathrm{CO}_{2}$ estimation was done immediately from $\mathrm{NaOH}$ solution. The fermentation broth was centrifuged at $4000 \mathrm{rpm}$ for $10 \mathrm{~min}$ and filtered through Whatman filter paper-1.For recovery of ethanol, $100 \mathrm{ml}$ fermentation broth was centrifuged; filtered and $100 \mathrm{ml}$ of distilled water was added and subjected for distillation process in condenser.

\section{Estimation of ethanol}

Ethanol obtained by distillation was oxidized by acid potassium dichromate and measured 
calorimetrically at $600 \mathrm{~nm}$ using working and standard ethanol solution (5\%). From standard ethanol solutions, working standard solution of $1 \%, 2 \%, 3 \%, 4 \%$ and $5 \%$ were prepared. In order to estimate ethanol content, eight volumetric flasks of $50 \mathrm{ml}$ capacity were taken and labeled from 1 to $8.1 .0 \mathrm{ml}$ working standard solutions of $1 \%, 2 \%, 3 \%, 4 \%$ and $5 \%$ were added into flask no. 2 to 6,respectively; whereas, flask no. 7 and 8 were added with 0.5 and $1.0 \mathrm{ml}$ of distilled ethanol sample respectively. Then $25 \mathrm{ml}$ of acid potassium dichromate solution (Dissolve $3.4 \mathrm{~g} \mathrm{k}_{2} \mathrm{Cr}_{2} \mathrm{O}_{7}$ in $50 \mathrm{ml}$ distilled water in a $100 \mathrm{ml}$ capacity volumetric flask. Put it in ice bath and add 30 $\mathrm{ml}$ of concentrated $\mathrm{H}_{2} \mathrm{SO}_{4}$ in it, mix well and make up the volume up to the mark with distilled water) was added in all the flasks and incubated in water bath at $80^{\circ} \mathrm{C}$ for $15 \mathrm{~min}$ followed by cooling at room temperature under running tap water and distilled water added to make final volume to $50 \mathrm{ml}$. Optical density (O.D.) at $600 \mathrm{~nm}$ wavelength was measured; standard curve was prepared and ethanol concentration was calculated. Ethanol $(\mathrm{g} / \mathrm{l})$ is equivalent to the yield of $100 \mathrm{~g}$ of dried substrate.

In the present study all experiments were performed with the above mentioned treatments repeated thrice to ensure accuracy and means of all treatments were taken into consideration of each parameter for interpreting the results.

\section{Results and Discussion}

\section{Selection of substrate}

India being an agriculture country, large amounts of lignocellulosic wastes is generated through forestry and agricultural practices, paper-pulp industries, timber industries and many agro industries. These wastes have been insufficiently disposed off leading to environmental pollution (Fabiyi et al., 2011).
Such renewable resources are becoming increasingly important, plentifully available in nature and have a potential for bioconversion into fuels and chemicals, both natural and man-made (Thompson et al., 1999), to change the world economically, socially, and environmentally (Sanchez, 2009).Amongst six natural lignocellulosic waste/raw materials viz., cotton seed cake, rice husk, millet straw, mustard straw, wheat straw and leaf litter screened, millet straw contained maximum cellulose of $30 \%$ followed by mustard straw (28\%), wheat straw (24\%), leaf litter $(23 \%)$, rice husk (20\%) and cotton seed cake (19\%) as estimated by colorimetric method. Owing to maximum cellulose content, millet straw was selected as substrate. Cotton seed cake, wheat straw and rice husk are widely used as food for animals in India because they provide enough energy and protein to meet an animal's requirement. Besides this, there is limited availability of mustard straw in local region; furthermore, biochemical composition of leaf litter is variable and diseases and insecticides application interfering with the final results; hence, leaf litter is also not ideal choice for cellulase biosynthesis. In India, every year 64.4 million tones millet is produced with processing of millet grains. Besides, millet waste as animal feed is limited. Considering these, millet straw seems ideal choice on account of higher cellulose content and negligible lignin, plentiful and easy availability in local region. Bioethanol production from sugarcane and maize were well known in South Gujarat. Considering ample availability in rain fed area and high cellulose content as well as little work on enzymatic hydrolysis and potential of bioethanol production, millet straw was selected as substrate for further experimentation. Wu et al., (2006) reported that the pearl millet could be a potential feedstock for ethanol production in bioreactor using fermenting yeast, Saccharomyces cerevisiae in rain fed region where wheat and 
other grain crops could not be raised owing to shortage of moisture.

\section{Pretreatment of the substrate}

Pretreatment of lignocelluloses is intended to disorganize the crystalline structure of macro and micro fibrils in order to increase the polymer chains of cellulose and hemicelluloses and modify the pores in the material to allow the enzyme to penetrate into the fibers to render them amenable to enzymatic hydrolysis. Physical pretreatment is intended to increase accessible surface area and size of pores, partial hydrolysis of hemicelluloses and partial depolymerization of lignin (Sun and Cheng, 2002). When substrates were grinded mechanically, substrate of $3 \mathrm{~mm}$ particle size showed 3.703 U/gds enzymatic activities which were higher than that obtained through $1 \mathrm{~cm}$ particle size (0.462 U/gds).Cellulose degradation was found to be decrease with increase alkali concentration (Table 1). Basically, pretreatment is a delignification process, and the underlying mechanism is the saponification of intermolecular ester bonds cross linking xylan hemicelluloses and lignin (Sun and Cheng, 2002). In addition, alkaline pretreatment also removes acetyl and other acidic substitutions on hemicelluloses that protect cellulose from attack by cellulase (Chang and Holtzapple, 2000). Various alkalis including sodium hydroxide, lime and aqueous ammonia have been studied (Gupta and Lee, 2010; Kim et al., 2003). Considering these, millet straw was treated with five different concentrations of alkaline treatments viz., $1 \mathrm{~N}$, $2 \mathrm{~N}, 3 \mathrm{~N}, 4 \mathrm{~N}$ and $5 \mathrm{~N} \mathrm{NaOH}$ solutions. The maximum enzyme activity (3.549U/gds) was observed with $1 \mathrm{~N} \mathrm{NaOH}$. As concentration of $\mathrm{NaOH}$ was increased, there was decrease in cellulase degradation (Table 1). This was due to higher concentration of alkali which causes rapid accumulation of volatile fatty acids which inhibits the cellulosic activity while lower concentration may prolong the time of degradation ( $\mathrm{Gu}$ et al., 2014; Chandra et al., 2012; Zhou et al., 2011). Increased cellulase activity at $1 \mathrm{~N} \mathrm{NaOH}$ concentration might be due to increased solubilization of lignin and increase in swelling of cellulose I to II. Koullas et al., (1992), Aguiar et al., (2001) and Vyas et al., (2005) also reported $1 \mathrm{~N}$ $\mathrm{NaOH}$ pretreatment of lignocellulosic substrates best for cellulase production.

\section{Physico-chemical parameters of the millet straw}

The composition of selected substrate (millet straw) showed $30 \%$ cellulose, $10 \%$ hemicellulose, $8.73 \%$ total organic carbon, $0.7 \%$ total nitrogen and $0.8 \mathrm{ppm}$ phosphorous (Table 2). In solid state fermentation, enzyme production was carried out using lignocellulosic biomass. Cellulose and hemicelluloses are used as carbon source for the production of cellulolytic and hemicellulolytic enzymes. Furthermore, cellulose and hemicelluloses are the effective inducer for cellulolytic and hemicellulolytic enzymes respectively and millet straw is rich in cellulose and hemicellulose.

\section{Microorganism selection and Inoculum Preparation}

The ability to secrete large amounts of extracellular cellulase is characteristics of certain fungi. Moreover, fungi have ability to produce higher amount of enzymes than bacteria (Amouri and Gargouri, 2006). Cellulase characteristics and production by Aspergillus spp. have been well documented in the literature (Lockington et al., 2002; Ong et al., 2004 and Wang et al., 2006). Therefore fungi viz., Aspergillus oryzae, Aspergillus flavus, Aspergillus niger and Aspergillus fumigatus isolated from local soil dumps of kitchen and garden waste were grown on Carboxy Methyl Cellulose (CMC) agar 
medium and examined for cellulolytic enzyme activity. Fungus, Aspergillus flavus showed higher cellulose activity (4.012 U/gds) than other three species (Table 3). The culture of Aspergillus flavus showing high cellulase activity was selected and grown on PDA slants and the spores were harvested aseptically from 5 day old PDA slants. The slants were freshly made twice in a month and stored at $4{ }^{\circ} \mathrm{C}$.

Sterile distilled water $(10 \mathrm{ml})$ was added to each fungal slant and vortexed. Spore count was measured in Neubers Chamber and adjusted to $10^{7} \mathrm{spores} / \mathrm{ml}$ by adjusting absorbance maxima. The potentiality of Aspergillus flavusas one of the potent lignocellulolytic organisms for cellulose production was also reported by Solomon et al., (1999). Ojumu et al., (2003) also found that Aspergillus flavus grown on sawdust gave the highest cellulase activity of $0.0743 \mathrm{IU} / \mathrm{ml}$ than bagasse and corncob.

\section{Selection of fermentation medium}

In order to obtained good biosynthesis of cellulose, five different media were used for enzyme activity and Mandels and Sternberg medium showed maximum enzyme activity (4.629 ${\mathrm{U} . \mathrm{gds}^{-1}}^{\text {) }}$ (Table 4). The composition of medium $(\mathrm{g} / \mathrm{l})$ includes Urea $0.3 \mathrm{~g},\left(\mathrm{NH}_{4}\right)_{2} \mathrm{SO}_{4}$ $1.4 \mathrm{~g}, \quad \mathrm{KH}_{2} \mathrm{PO}_{4} 2.0 \mathrm{~g}, \mathrm{CaCl}_{2} 0.3 \mathrm{~g}$, $\mathrm{MgCl}_{2} .7 \mathrm{H}_{2} \mathrm{O} 0.3 \mathrm{~g}$, Protease peptone $1.0 \mathrm{mg}$, $\mathrm{FeSO}_{4} .7 \mathrm{H}_{2} \mathrm{O} 5.0 \mathrm{~g}, \quad \mathrm{MnSO}_{4} .7 \mathrm{H}_{2} \mathrm{O} 1.6 \mathrm{~g}$, $\mathrm{ZnSO}_{4} .7 \mathrm{H}_{2} \mathrm{O} 1.4 \mathrm{~g}$, Tween-80 0.1\%(v/v) at $\mathrm{pH}$ 5.2 .

The medium showed maximum enzyme activity due to favorable $\mathrm{pH}$ and supplementing nitrogen and mineral requirements for growth and development of Aspergillus flavus. This medium was selected for solid state fermentation using Aspergillus flavus for enzymatic hydrolysis. The cellulase hydrolyzing activity is further improved by some metal ions $\mathrm{Mg}^{2+}, \mathrm{Mn}^{2+}, \mathrm{K}^{+}$and $\mathrm{Ca}^{2+}$ (Zhang et al., 2012).Urea provides nitrogen which is essentially important for cell growth and building block of enzymes. Stimulation of endoglucanase activity by ammonium salt may be due to their direct entry into protein synthesis. In the current study Tween 80 was used as a surfactant. Wu and $\mathrm{Ju}$, (1998) reported enhanced enzymatic saccharification of waste newsprint by addition of surfactant like Tween 20 or Tween 80 . The rate of enzymatic hydrolysis was improved by $33 \%$ using Tween 80 as a surfactant in the hydrolysis of newspaper (Castanon and Wilke, 1981).

\section{Optimization for enzymatic hydrolysis}

Optimization is important aspect in order to find out suitable growth condition for maximum biosynthesis of cellulolytic enzyme. Various parameters such as inoculum size, $\mathrm{pH}$, temperature, incubation time, moisture content, substrate concentration, carbon source and nitrogen source were studied for optimization for maximum CMCase biosynthesis (Table 5).

\section{Effect of inoculum size on CMCase biosynthesis}

Pretreated millet straw @3g wetted with Mandles and Stenberg medium was loaded with different concentrations of inoculum $(0.5$ $\mathrm{ml}, 1.0 \mathrm{ml}, 1.5 \mathrm{ml}, 2.0 \mathrm{ml}, 2.5 \mathrm{ml}$ and $3.0 \mathrm{ml}$ ) and incubated at room temperature $\left(28^{\circ} \mathrm{C}\right)$ for 7 days. The results revealed that optimum inoculum size for CMCase synthesis by Aspergillus flavus was $1.0 \mathrm{ml}$ showing maximum CMCase activity of $4.7830 \mathrm{U} / \mathrm{gds}$ (Table 5). It was observed that the increase in the inoculum size yielded gradual reduction in the enzyme activity. This decrease in enzyme activity with further increase in inoculum might be due to clumping of cells which could have reduced sugar and oxygen uptake rate 
and in turn reduced release of enzyme (Srivastava et al., 1987). Nadagouda et al., (2016) reported that lower inoculum size resulted in longer time for substrate utilization and cellulase release. While too high inoculum size may lead to rapid fungal biomass synthesis up to certain limit, after that the completion and interaction may lead to affect enzyme synthesis. This might be due to the nutrient depletion in biomass enhancement owing to completion, which may affect rate of metabolic activity. Hence, the inoculam size of $1.0 \mathrm{ml}$ showing high cellulase activity seems optimum for conducting further studies in rotary shaker experiment.

\section{Effect of pH on CMCase biosynthesis}

The $\mathrm{pH}$ of the medium was adjusted to4.0, 4.5, 5.0, 5.5, 6.0, 6.5 and 7.0 by adding required amount of $1 \mathrm{~N} \mathrm{HCl}$ and $1 \mathrm{~N} \mathrm{NaOH}$ and $1 \mathrm{ml}$ of inoculam was added and finally incubated at room temperature $\left(28^{\circ} \mathrm{C}\right)$ for 7 days. The biosynthesis of enzyme was found to be maximum $(5.092 \mathrm{U} / \mathrm{gds})$ when $\mathrm{pH}$ of the medium was maintained at 4.5, more over when the $\mathrm{pH}$ level increased, the enzyme production was decreased (Table 5).

The initial $\mathrm{pH}$ of the medium has a great effect on the growth of the organism, permeability in membrane, as well as on the biosynthesis and stability of the enzymes (Shoichi et al., 1985; Poorna and Prema, 2007). It was reported that optimum $\mathrm{pH}$ for CMCase from Aspergillus aculetus was found to be 4.5 to 5.0 (Murao et al., 1988). Akiba et al., (1995) reported that the production was high at $\mathrm{pH} 4.0$ and 4.5 by A. niger. Coral et al., (2002) observed that the enzyme activity has a broad $\mathrm{pH}$ range between 3 and 9. These might be due to the fact that the enzyme system within the same species may vary, depending on the strain under study. Based on the results obtained, the $\mathrm{pH}$ of the medium was adjusted to 4.5 for A. flavus in subsequent experiments.

\section{Effect of temperature on CMCase biosynthesis}

Amongst different incubating temperatures $\left(23^{\circ} \mathrm{C}, 28^{\circ} \mathrm{C}, 37^{\circ} \mathrm{C}\right.$, and $\left.50^{\circ} \mathrm{C}\right)$, the maximum CMCase biosynthesis was observed in flasks incubated at $28^{\circ} \mathrm{C}(6.018 \mathrm{U} / \mathrm{gds})$ (Table 5). As the temperature increased, there was gradual decrease in the enzyme biosynthesis which might be due to fact that too high temperature could change membrane composition and could cause the protein catabolism and inhibition of fungal growth. Shahriarinour et al., (2011) found the optimum temperature of $28^{\circ} \mathrm{Cforbetter}$ growth and cellulase production by $A$. terreus. Jadhav et al., (2013) reported $30^{\circ} \mathrm{C}$ as best temperature for cellulase production by Aspergillus niger from the rice husks, millet husks, wheat bran and banana peels. The slight difference in the incubating temperature condition might be due to different favourable range for different species and substrate composition.

\section{Effect of incubation time on CMCase biosynthesis}

Incubation time is required for appropriate growth and adaptation in the environment. The enzymatic hydrolysis study was carried out for different periods from 48 to $240 \mathrm{~h}$ by adding $1.0 \mathrm{ml}$ inoculum of Aspergillus flavus in the flask keeping $\mathrm{pH}$ of the medium 4.5 and incubating at the temperature of $28^{\circ} \mathrm{C}$. At every $24 \mathrm{~h}$ interval enzymatic activity was measured. The biosynthesis of enzyme increased with the incubation period and reached upto maximum activity $(6.790 \mathrm{U} / \mathrm{gds})$ at 120 hours of incubation (Table 5).

Further increase in incubation period resulted in the decreased production of cellulase. The incubation time of $120 \mathrm{~h}$ was also reported ideal for Aspergillus niger $\mathrm{kk}_{2}$ (Ojumu et al., 2003) as well as for Aspergillus phoenix (Dedavid et al., 2008). 


\begin{tabular}{|c|c|}
\hline \multicolumn{2}{|c|}{ Table.1 Comparison of chemical pretreatment for delignification } \\
\hline Alkaline (NaOH) treatment normality (N) & Enzyme activity (U/gds) \\
\hline $\mathbf{1}$ & 3.549 \\
\hline $\mathbf{2}$ & 3.395 \\
\hline $\mathbf{3}$ & 2.932 \\
\hline $\mathbf{4}$ & 2.623 \\
\hline $\mathbf{5}$ & 1.540 \\
\hline
\end{tabular}

Table.2 Physico-chemical parameters of the selected sulbstrate (millet straw)

\begin{tabular}{|r|l|l|l|c|}
\hline No. & Parameter & $\begin{array}{l}\text { Estimation } \\
\text { Method }\end{array}$ & \multicolumn{1}{c|}{ Reference } & Content \\
\hline $\mathbf{1}$ & Cellulose & Colorimetric & S. K. Thimmaiah & $30 \%$ \\
\hline $\mathbf{2}$ & Hemicellulose & Gravimetric & S. K. Thimmaiah & $10 \%$ \\
\hline $\mathbf{3}$ & Total Organic Carbon & Titrometric & Weakly and Black, 1934 & $8.73 \%$ \\
\hline $\mathbf{4}$ & Total Nitrogen & Nessler & Snell and Snell, 1995 & $0.7 \%$ \\
\hline $\mathbf{5}$ & Phosphorus & Colorimetric & Jackson, 1967 & $0.8 \mathrm{ppm}$ \\
\hline
\end{tabular}

Table.3 Selection of organism for cellulase activity

\begin{tabular}{|c|c|}
\hline Fungi & CMCase activity (U/gds) \\
\hline Aspergillus oryzae & 2.932 \\
\hline Aspergillus flavus & 4.012 \\
\hline Aspergillus niger & 2.777 \\
\hline Aspergillus fumigates & 1.234 \\
\hline
\end{tabular}

\section{Table.4 Effect of growth medium on cellulase activity}

\begin{tabular}{|l|}
\hline Medium \\
\hline Mineral Salt \\
\hline Mandles and Sternberg \\
\hline Berg \\
\hline Waber and Mandles \\
\hline Czapek-Dox \\
\hline
\end{tabular}

\begin{tabular}{|c|}
\hline CMCase activity $\left(\mathbf{U . g d s}^{-\mathbf{1}}\right)$ \\
\hline 2.930 \\
\hline 4.629 \\
\hline 3.549 \\
\hline 3.240 \\
\hline 2.160 \\
\hline
\end{tabular}

Table.6 Enzyme biosynthesis at optimized parameters under solid state fermentation

Substrate

Millet Straw

\section{CMCase activity (U/gds)}

Unoptimized condition*

4.012
Optimized condition 10.648

Table.7 Bioethanol production from millet straw through yeast fermentation

\begin{tabular}{|l|l|l|l|}
\hline $\begin{array}{l}\text { Incubation Period } \\
\text { Hours }\end{array}$ & $\begin{array}{l}\text { Ethanol Concentration } \\
\text { from graph }(\boldsymbol{\%})\end{array}$ & $\begin{array}{l}\text { Ethanol } \\
\text { Concentration }(\mathbf{g} / \mathbf{l})\end{array}$ & $\begin{array}{l}\text { Productivity } \\
\text { (g/hr/lit) }\end{array}$ \\
\hline 120 & 1.15 & 18.46 & 0.15 \\
\hline
\end{tabular}


Table.5 Optimization parameters for CMCase biosynthesis using millet straw as substrate under solid state fermentation

\begin{tabular}{|c|c|c|c|c|c|c|c|}
\hline \multicolumn{2}{|c|}{ Inoculam size } & \multicolumn{2}{|c|}{ pH } & \multicolumn{2}{|c|}{ Temperature } & \multicolumn{2}{|c|}{ Incubation time } \\
\hline $\begin{array}{l}\text { Inoculam } \\
\text { (ml) }\end{array}$ & $\begin{array}{l}\text { CMCase } \\
\text { activity } \\
\text { (U/gds) }\end{array}$ & pH & $\begin{array}{l}\text { CMCase } \\
\text { activity } \\
\text { (U/gds) }\end{array}$ & $\begin{array}{c}\text { Temperature } \\
\left({ }^{\circ} \mathrm{C}\right)\end{array}$ & $\begin{array}{l}\text { CMCase } \\
\text { activity } \\
\text { (U/gds) }\end{array}$ & $\begin{array}{c}\text { Incubation } \\
\text { time } \\
\text { (hours) }\end{array}$ & $\begin{array}{l}\text { CMCase } \\
\text { activity } \\
\text { (U/gds) }\end{array}$ \\
\hline 0.5 & 0.617 & 4.0 & 4.012 & 23 & 0.771 & 48 & 3.308 \\
\hline 1 & 4.783 & 4.5 & 5.092 & 28 & 6.018 & 72 & 5.401 \\
\hline 1.5 & 4.012 & 5.0 & 4.783 & 37 & 3.086 & 96 & 5.555 \\
\hline 2 & 2.777 & 5.5 & 1.697 & 50 & 2.314 & 120 & 6.790 \\
\hline 2.5 & 1.543 & 6.0 & 1.388 & & & 144 & 6.018 \\
\hline \multirow[t]{4}{*}{3} & 1.080 & 6.5 & 1.080 & & & 168 & 4.938 \\
\hline & & 7.0 & 0.617 & & & 192 & 4.783 \\
\hline & & & & & & 216 & 4.629 \\
\hline & & & & & & 240 & 4.475 \\
\hline \multicolumn{2}{|c|}{ Moisture content } & \multicolumn{2}{|c|}{ Substrate concentration } & \multicolumn{2}{|c|}{ Carbon source } & \multicolumn{2}{|c|}{ Nitrogen source } \\
\hline $\begin{array}{c}\text { Moisture } \\
\text { content }(\%)\end{array}$ & $\begin{array}{l}\text { CMCase } \\
\text { activity } \\
\text { (U/gds) }\end{array}$ & $\begin{array}{c}\text { Substrate } \\
\text { concentration } \\
\text { (g) }\end{array}$ & $\begin{array}{l}\text { CMCase } \\
\text { activity } \\
\text { (U/gds) }\end{array}$ & $\begin{array}{c}\text { Carbon } \\
\text { source (g) }\end{array}$ & $\begin{array}{l}\text { CMCase } \\
\text { activity } \\
\text { (U/gds) }\end{array}$ & $\begin{array}{c}\text { Nitrogen } \\
\text { source } \\
\text { (g) }\end{array}$ & $\begin{array}{l}\text { CMCase } \\
\text { activity } \\
\text { (U/gds) }\end{array}$ \\
\hline 40 & 6.635 & 1 & 7.870 & Glucose & 6.635 & Ammonium nitrate & 8.029 \\
\hline 50 & 7.253 & 3 & 9.104 & Sucrose & 7.870 & Ammonium sulphate & 9.722 \\
\hline 60 & 7.870 & 5 & 6.851 & CMC & 9.259 & Yeast extract & 7.561 \\
\hline 70 & 8.333 & 7 & 3.502 & Xylose & 8.179 & Protease peptone & 7.253 \\
\hline \multirow[t]{2}{*}{80} & 6.018 & 10 & 1.712 & Wheat flour & 6.790 & Urea & 6.327 \\
\hline & & & & Cellobiose & 6.635 & & \\
\hline
\end{tabular}


Datt and Kumar (2012) found that the CMCase activities of Aspergillus flavus AT-2 increased steadilywith increasing incubation period and attained maximum $(9.20 \mathrm{IU} / \mathrm{ml})$ on the $5^{\text {th }}$ day $(120 \mathrm{~h})$ of incubation. Okonkwo et al., (2014) also reported that Aspergillus flavus culture may be effectively harvested in their highest cellulase production capacity in 5 days $(120 \mathrm{~h})$. The possible reason for decreased enzyme activity is associated with the fact that the enzyme production in various microorganisms reached the maximum level in stationary phase and declined during the death phase. During the death phase, depletion of nutrient concentration and cellular fragmentation is very common, resulting in release of intracellular material and proteases in fermentation broth (Dhillon et al., 2011; Bansal et al., 2012). By considering these, incubation time was selected as $120 \mathrm{~h}$ for subsequent studies.

\section{Effect of moisture content on CMCase biosynthesis}

The moisture content of substrate is the key factor in SSF because it affects growth, biosynthesis and secretion of enzymes. The maximum CMCase activity (8.333 U/gds) was found at $70 \%$ moisture content (Table 5). Lower moisture content caused the solubility of substrate, low degree of swelling and high water tension (Moo-young et al., 1983). Inter particle mass transfer of oxygen; nutrients and enzyme are dependent on substrate characteristics and moisture content of fermenting media. Contrary, at higher moisture content, void space within solid phase is filled with water and air is driven out, affecting growth of fungus and ultimate enzyme synthesis. Xia et al., (1999) found maximum cellulase production under SSF at water content of 70per cent. Liang et al., (2012) also observed highest cellulase activity at $70 \%$ moisture content by incubating with Aspergillus sp. (SEMCC-3.248) in solid state fermentation. An increase or decrease in moisture content from the optimum value resulted in lower cellulase activities. A higher than optimum moisture content led to a decrease in porosity, gummy texture, and lower oxygen transfer whereas a lower moisture content led to decreased swelling of substrate and solubility of nutrients (Kaur et al.,2011). This inhibits effective uptake of nutrients by fungi. If moisture is too high during SSF, risk of contamination by unfavorable microorganisms is greater (Yoon et al., 2014).

\section{Effect of substrate concentration on CMCase biosynthesis}

The pretreated substrate at $70 \%$ moisture content was suspended in fixed volume (10 $\mathrm{ml})$ of buffer $(\mathrm{pH} 4.5)$ with different weights $(1.0,3.0,5.0,7.0$ and $10.0 \mathrm{~g})$ and $1.0 \mathrm{ml}$ inoculum was added and incubated for $120 \mathrm{~h}$ at $28^{\circ} \mathrm{C}$. $3 \mathrm{~g}$ pretreated substrate showed higher CMCase activity (9.104 U/gds) (Table $5)$. Increased in quantity of substrate and concentration, there was reduction in enzyme activity. Increase in substrate concentration limits the saccharification yields because of stirring difficulties, reduction of aqueous movable phase and end product inhibition (Szczodrak 1999). The present results was in accordance with Vyas et al., (2005) who also reported $2 \%$ substrate concentration was optimum for maximum endoglucanase activity $(2.889 \mathrm{IU} / \mathrm{ml})$.

\section{Effect of carbon source on CMCase biosynthesis}

The carbon source is one of the most important nutrients for the biosynthesis of enzyme. The substrates not only serve as a carbon source but also produce the necessary inducing compounds for the organisms (Haltrich et al., 1996). In our study, influence of supplementation of different carbon source 
such as glucose, sucrose, carboxy methyl cellulose (CMC), xylose, wheat flour and cellobiose in $0.1 \%$ concentration to Mandles and Sternberg medium on cellulase production by Aspergillus flavus was tested. Amongst carbon sources tested, carboxy methyl cellulose showed higher CMCase activity (9.259 U/gds) (Table 5). Earlier it has been reported that endoglucanase was induced by CMC but repressed by glucose (Ahmed et al., 2005). It was also found that CMC was preferred substrate for endoglucanase production (Lucas et al., 2001). Similarly, Malik et al., (1986) reported that negligible cellulases were produced with glucose as carbon source from $T$. harzianum. Niranjane et al., (2007) observed highest yields of cellulase on CMC. In the present study also similar results was noticed with less cellulase activities in the presence of glucose, while CMC proved to be a strong inducer of cellulase enzymes.

\section{Effect of nitrogen source on CMCase biosynthesis}

Nitrogen requirement of microbes used in SSF process are obtained from the substrate itself in same instance, whereas supplementation of additional nitrogen in organic or inorganic form is often reduced. In this study, effects of nitrogen source viz., ammonium nitrate, ammonium sulphate, yeast extract, protease peptone and urea were tested at $0.5 \%$ concentration individually. Amongst them, ammonium sulphate showed highest enzyme activity (9.722 U/gds) (Table 5). Nitrogen is the major constituent of protoplasm building block of enzyme (proteins). Stimulation of endoglucanase activity by ammonium sulphate may be due to their direct entry in protein synthesis (Mandels, 1975). The present finding in accordance with the result of Linko et al., (1978) who reported ammonium salt to be excellent source of nitrogen for cellulose production by Trichoderma $s p$. Similarly, Sasi et al., (2012) reported that A. flavus showed the highest production of cellulase enzyme utilizing ammonium sulphate as nitrogen source than yeast extract. Sethi and Gupta, (2014) observed ammonium sulphate as the best nitrogen source for Aspergillus niger. The enzyme production was remarkably decreased in presence of urea (Acharya et al., 2008).

\section{Enzymatic hydrolysis under solid state fermentation at optimized condition}

Based on the above results on optimization parameters, the flasks containing 3 gof millet straw was wetted with $10 \mathrm{ml}$ of Mandles and Sternberg medium, at $\mathrm{pH} 4.5$, with $70 \%$ moisture content; autoclaved at $121^{\circ} \mathrm{C}$ at 151 lbs; inoculated with $1.0 \mathrm{ml}$ Aspergillus flavus $\left(1 \times 10^{7}\right.$ spores $\left./ \mathrm{ml}\right)$ and incubated at $28^{\circ} \mathrm{C}$ for 120 h. Simultaneously, enzymatic hydrolysis also carried out with unoptimized condition

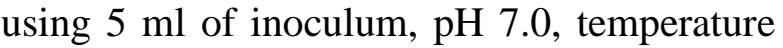
$50^{\circ} \mathrm{C}, 40 \%$ moisture content, $10 \mathrm{~g}$ of substrate providing cellobiose and urea as carbon and nitrogen source respectively. The CMCase activity was enhanced considerably from 4.012 observed before optimization to 10.648 U/gds after optimization (Table 6).

\section{Ethanol production}

Ethanol fermentation was performed in flasks on a rotary shaker using yeast, Saccharomyces cerevisiae. The ethanol production was $18.46 \mathrm{~g} / \mathrm{l}$ from $100 \mathrm{~g}$ dried millet straw when incubated for $120 \mathrm{~h}$ at optimized parameters and fermented through yeast Saccharomyces cerevisiae (Table 7).

Millet straw seems ideal choice on account of ample availability in rain fed region, higher cellulose content and negligible lignin in local region and amenable to high cellulase activity after pre-treatment. Aspergillus flavus was the 
potent culture for synthesis of cellulose under solid state fermentation with $1.0 \mathrm{ml}$ inoculam size. The organism gave good activity at $\mathrm{pH}$ $4.5,28^{\circ} \mathrm{C}$ temperature and $3 \mathrm{~g}$ substrate concentration for $120 \mathrm{~h}$ incubation period. In addition, $70 \%$ (w/w) moisture content, $0.1 \%$ $\mathrm{CMC}$ and $0.5 \%$ ammonium sulphate enhanced cellulase activity. The CMCase activity was $4.012 \mathrm{U} / \mathrm{gds}$ before optimization which was found to be increased upto 10.648 U/gds after optimization. The biodegradation of cellulose further applied for the production of ethanol through yeast fermentation. The hydrolysate was undergone to saccharification and it was observed that $0.15 \mathrm{~g} / \mathrm{h} / \mathrm{lit}$ ethanol can be produced.

This study also indicates that millet straw is most suitable raw material for cellulase production as it gave maximum biosynthesis of enzyme. The bioethanol obtained by hydrolysis and saccharification was highly satisfactory and eco-friendly energy source produced from lignocellulosic waste millet straw. Hence, it is promising lignocellulosic feedstock for bioethanol production through fermentation by Saccharomyces cerevisiae. This work will not only benefit the fuel ethanol industry in semi-arid or arid rural areas by finding alternative raw materials but will also provide valuable information for breeders to modify existing millet genotypes amenable for improving genotypes for maximum cellulase activity and bioethanol production.

\section{Acknowledgments}

Authors are highly thankful to Dr. Pratik Shilpakar, Lecturer; Dr. Nikhil Bhatt, Research Scientist and Dr. Srinivas Murthy, Research Scientist from Biogas Research Center, Gujarat Vidyapeeth, Sadra, Gandhinagar, Gujarat for providing valuable feedback and guidance for conducting the work.

\section{References}

Acharya, P. B., Acharya, D. K. and Modi, H. A. 2008. African Journal of Biotechnology. 7(22): 4147.

Aguiar, C.L. 2001. Biodegradation of cellulose from sugar bagasse by fungal cellulase. Cienc. Tecnol. Eliment. 3: 117-121.

Ahmed, S., N. Aslam, F. Latif, M.I. Rajoka and A. Jamil. 2005. Molecular cloning of cellulase genes from Trichoderma harzianum. In: Proceedings of the 9th International Symposium on Natural Product Chemistry, Frontiers in Natural Product Chemistry. Vol 1, (Eds.): Atta-urRehman, I. Choudhary, M. Khan. pp. 7375. Bentham Science Publishers Ltd. TheNetherlands.

Akiba, S., Y. Kimura, K. Yamamoto and H. Kumagai. 1995. Purification and characterization of a protease-resistant cellulase from Aspergillus niger. J. Fermen. Bioeng.79: 125-130.

Amouri, B. and Gargouri, A. 2006. Characterization of a Novel $\beta$-Glucosidase from a Stachybotrys Strain. Biochemical Engineering Journal32: 191-197.

Bansal, N., Soni, R., Janveja, C., Soni and S.K. 2012. Production of xylanase-cellulase complex by Bacillus subtilis NS7for the biodegradation of agro-waste residues. Lignocellulose 1:196-209.

Castanon, M. and Wilke, C.R. 1981. Effects of the surfactant Tween 80 on enzymatic hydrolysis of newspaper. Biotechnol. Bioeng. 23: 1365-1372.

Chandra, R., Takeuchi, H., Hasegawa, T. and Kumar, R. 2012. Improving biodegradability and biogas production of wheat straw substrates using sodium hydroxide and hydrothermal pretreatments. Energy 43: 273-282.

Chang, V.S. and Holtzapple, M.T. 2000. Fundamental factors affecting biomass enzymatic reactivity. Appl Biochem Biotechnol 84-86:5-37

Coral, G.K., B. Arikan, M.N. Unaldi and H. Guvenmez. 2002. Some properties of crude carboxymethyl cellulase of Aspergillus niger Z10 Wild-Type Strain. Turk. J. Bio. 26: 209-213. 
Datt, D. and Kumar, A. 2014. Optimization of cellulase production under solid-state Fermentation by Aspergillus flavus (AT-2) and Aspergillus niger (AT-3) and its impact on stickies and Ink particle size of sorted office paper. Cellulose Chem. Technol. 48(3-4): 285-298.

De Ruyck, J., Allard, G. and Maniatis, K.1996. An externally Wred evaporative gas turbine cycle for small scale biomass CHP production. In: Chartier $\mathrm{P}$ et al., (eds) Proceedings of the 9th European Bioenergy conference, Pergamon, Oxford.

Dedavid, E.S.L.A., Lopes, F.C., Silveira, S.T. and Brandeli, A. 2008. Production of cellulytic enzyme by Aspergillus phonenicis in grape waste using response surface methodology. Applied Biochemistry Biotechnology. DOI 10.1007/s12010-008-8190-7.

Deobald, L.A. and Crawford, D.L. 1997. Lignocellulose biodegradation. In: Hurst, C.J., Knudsen, G.R., Stetzenbach, L.D. and Walter, M.V. (Eds) Manual of Environmental Microbiology pp 730-737. ASM Press, Washington D C, USA.

Dhillon, G.S., Oberoi, H.S., Kaur, S., Bansal, S. and Brar, S.K., 2011. Value-addition of agricultural wastes for augented cellulase and xylanase production through solid-state tray fermentation employing mixed-culture of fungi. Ind. Crop Prod. 34: 1160-1167.

Fabiyi, L.L. and Ogunfowora, A. 2011. Economics of production and utilization of organic fertilizer in the Nigerian agriculture. Proceedings of a National Organic Fertilizer Seminar, Mar. 26-27, Zaria, Niger, pp: 138-145.

FAOSTAT 2006. FAO statistical databases. http://faostat.fao.org/

Gu. Y, Chen. X, Liu. Z, Zhou, X. and Zhang, Y. 2014. Effect of inoculum sources on the anaerobic digestion of rice straw. Bioresour. Technol. 158: 149-155.

Gupta, R. and Lee, Y.Y.2010. Pretreatment of corn stover and hybrid poplar by sodium hydroxide and hydrogen peroxide. Biotechnol. Prog. 26:1180-1186.

Haltrich, D., Nidetzky, B., K.D. Kuble, Steiner, W. and Zupancic, S. 1996. Production of fungal xylanases. Bioresource Technology. 58:137-161.
Jackson, M. L. 1973. Soil Chemical Analysis, Prentice Hall of India Pvt. Ltd, New Delhi.

Jadhav A.R., Girde A.V., More S.M., More S.B. and Saiqua Khan, 2013. Cellulase production by Utilizing Agricultural Wastes. Research Journal of Agriculture and Forestry Sciences 1(7):6-9.

Kaur, H., Dutt, D. and Tyagi, C.H. 2011. Production of novel alkali-thermo-tolerant cellulase-poor xylanases from Coprinopsis Cinerea HK-1 NFCCI-2032. Bioresources 6: 1376-1391.

Kaylen M, Van Dyne DL, Choi YS and Blase M, (2000). Economic feasibility of producing ethanol from lignocellulosic feedstocks. Biores. Technol. 72: 19-32.

Kim, T.H., Kim J.S. and Sunwoo, C. 2003. Pretreatment of corn stover by aqueous ammonia. Bioresour. Technol. 90:39-47.

Koullas, D.P., Christakopoulos, P., Kakos, D., Makris, B.J. and Koukios, E.G. 1992. Correlating the effect of pretreatment on enzymatic hydrolysis of straw. Biiotechnol. Bioeng. 38:113-116.

Lee, J. 1997. Biological conversion of lignocellulosic biomass to ethanol. J. Biotechnol. 56: 1-24.

Liang, X., Huang, Y., Hua, D., Zhang, J., Xu, H., Li, Y. and Zhang, X. 2012. Cellulase Production by Aspergillus sp.on Rice Grass (Spartina spp.) under Solid-State Fermentation. African Journal of Microbiology Research. 6: 6785-6792.

Linko, Markkaneu, M. P. and Barely, M. 1978. Production of cellulase and hemicellulase by Trichoderma viridae bioconversion. Cellulase Substrate Energy Chemical Microbiology $\left(1^{\text {st }}\right)$ 1977: 329-350.

Lockington, R.A., Rodbourn, L., Barnett, S., Carter, C.J. and Kelly, J.M. 2002. Regulation by carbon and nitrogen sources of a family of cellulases in Aspergillus nidulans. Fung. Gen. Biol.37: 190-196.

Lucas, R., Robles, A., Garcia, M.T., Alvarez, De, Cienfuegos, G. and Galvez, A. 2001. Production, purification and properties of an endoglucanase produced by the hyphomycete Chalara (syn. Thielaviopsis paradoxa $\mathrm{CH} 32$ ). Journal of Agri. Food Chem. 49: 79-85.

Malik, N.N., M.W. Akhtar and B.A. Naz. 1986. 
Production of cellulase enzymes by Trichoderma harzianum. Poster Abstract. PAEC-KFK. Symp. Workshop on Biotechnology in Agriculture and Energy, March 3-7, 10: Faisalabad.

Mandels, M. 1975. Microbial sources of cellulase. Biotechnol Bioeng. 5: 81-105.

Mandels, M. and Sternberg, D. 1976. Recent advances in cellulase technology. Ferment. Technol. 54:267-286.

Mandels, M., Andreotti, R. and Roche, C. 1976. Measurement of saccharifying cellulase. Biotechnol. Bioeng. Symp. 21-33.

Miller, G.L. 1959. Use of dinitrosalicylic acid reagent for determination of reducing sugars. Annual Chemistry 31: 426-476.

Mitchell, W.J. 1998. Physiology of carbohydrate to solvent conversion by Clostridia. Adv Microbiol Physiol. 39: 31-130.

Moo-Young, M., Moreire, A.R. and Tengrady, R.R.1983. Filamentous fungi 4 (Oxford/IBH Publication, New Delhi): 117.

Murao, S., Sakamoto, R. and Arai, M. 1988. Cellulase of Aspergillus aculeatus. In: Methods in enzymology, Academic press. 160: 275-284.

Nadagouda, M.G., K. Lingappa, V.S. Bheemareddy and S.G. Malipatil, 2016. Optimization of solid state fermentation conditions for the production of cellulase by using Trichoderma viride GSG12. Biosci. Discovery. 7: 1-6.

Niranjane, A.P., P. Madhou and T.W. Stevenson. 2007. The effect of carbohydrate carbon sources on the production of cellulose by Phlebia gigantean. Enzyme Microbiology. 30: 255-258.

Ojumu, T., Solomon, V., Bmidele, O., Betiku, E., Layokun, S.K. and Amigun, B. 2003. Cellulase production by Aspergillus flavus Linn. Isolate NSPR 101 fermented in saw dust, bagass and corn cob. African Journal of Biotechnology.2: 150-152.

Okonkwoa, I.F., Odibob, F.J.C. and Obelec, C.M. 2014. Time course for cellulase enzyme production by Aspergillus Flavus using different organic nitrogen sources. Scientific Journal of Biological Sciences. 3(2): 24-28.

Ong, L.G.A., Abd-Aziz, S., Noraini, S., Karim, M.I.A., Hassan, M.A., 2004. Enzyme production and profile by Aspergillus niger during solid Substrate fermentation using palm kernel cake as substrate. Appl. Biochem. Biotechnol. 118: 73-79.

Poorna, C.A. and P. Prema, 2007. Production of cellulase free endoxylanase from novel alkalophilic thermotolerent Bacillus pumillus by solid state fermentation and its application in wastepaper recycling. Bioresour. Tech. 98: 450-490.

Rajaram, S. and Verma, A. 1990. Production and characterization of xylanase from Bacillus thermoalkalophilus growth on agricultural wastes. Appl. Microbiol. Biotechnol. 34:141-144.

Sanchez, C. 2009. Lignocellulosic residues: Biodegradation and bioconversion by fungi. Biotechnol. Adv. 27: 185-194.

Sasi, A., M. Ravikumar, and S. Manthiri Kani. 2012. Optimization, production and purification of cellulase enzyme from marine Aspergillus flavus. African Journal of Microbiology Research Vol. 6(20): 4214-4218.

Sethi, S. and Gupta, S. 2014. Optimization of cultural parameters for cellulase enzyme production from fungi. Biolife 2 (3): 989996.

Shahriarinour, M., Abdul, W.M.N., Mohamad, R., Mustafa, S. and Ariff, A. B. 2011. Effect of medium composition and cultural condition on cellulase production by Aspergillus terreus. African Journal of Biotechnology Vol. 10(38): 7459-7467.

Shoichi, T., K. Xoighi and S. Hiroshi, 1985. Cellulase production by $P$. purpurogenum. J. Ferment. Technol. 62: 127-127.

Snell, F.D and Snell, C.T. 1954. Colorimetric determination of traces of metals. 2nd ed. Inter Sci. Publ. Inc. New York.

Solomon, B.O., Amigun, B., Betiku, E., Ojumu, T.V. and Layokun, S.K. 1999. Optimization of cellulose production by Aspergillus flavus Linn isolate NSPR 101 Grown on bagasse. JNSChE. 16: 61-68.

Srivastava, S.K., Gopalkrishnan, K.S. and Ramachandran, K.B. 1987. The Production of $\beta$ - Glucosidase in Shake-flasks by Aspergillus wentii. J. Ferment. Technol. 65(1): 95 -99.

Sun, Y. and Cheng, J. 2002. Hydrolysis of 
lignocellulosic material from ethanol production: A review. Biores. Technol. 83: $1-11$.

Szczodrak, J., Ilezuk, A., Rogalski, J., Leonowicz, A. 1999. Intensification of oak saw dust enzymatic hydrolysis by chemical or hydrothermal pretreatment. Process Biochem. 35:33-41

Thimmaiah, S.K. 2006. Standard Methods of Biochemical Analysis. Kalyani Publishers, New Delhi.

Thompson, D.N., Chen, H.C. 1992. Comparison of pretreatment methods on the basis of available surface area. Bioresour. Technol. 39: 155-163.

Vyas, A., Vyas, D. and Vyas, K.M. 2005. Production of fungal cellulases by solid state bioprocessing of ground nut shell wastes. Journal of Scientific and Industrial Research. 64: 767-770.

Waldrop, M.P., Balser, T.C. and Firestone, M.K. 2000. Linking microbial community composition to function in a tropical soil. Soil Biol. Biochem. 32: 1837-1846.

Walkley, A. and Black, I.A. 1934. An examination of Degtjareff method for determining soil organic matter and a proposed modification of the chromic acid titration method. Soil Sci. 37: 29-37.

Wang, X.J., Bai, J.G. and Liang, Y.X. 2006. Optimization of multienzyme production by two mixed strains in solid-state fermentation. Appl. Microbiol. Bbiotechnol.73: 533-540.

Wheals, A.E., Basso, L.C., Alves, D.M.G and Amorim, H.V. 1999. Fuel ethanol after 25 years. Trends Biotechnol. 17: 482-487.

$\mathrm{Wu}$, J. and Ju, L.K. 1998. Enhancing enzymatic saccharification of waste newsprint by surfactant addition. Biotechnol. Prog. 14: 649-652.

X. Wu, D. Wang, S. R. Bean, and J. P. Wilson, 2006. Ethanol Production from Pearl Millet Using Saccharomyces cerevisiae. Cereal Chem. 83(2):127-131.

Xia, L. and P. Cen 1999. Cellulase production by solid state fermentation on lignocellulosic wastes from the xylose industries. Process Biochemistry. 34: 909-912.

Yoon, L.W., Ang, T.N., Ngoh, G.C., Chua, A.S.M. 2014. Fungal solid-state fermentation and various methods of enhancement in cellulase production. Biomass Bioenerg. 67: 319-338.

Zhang, J., Tang, M. and Viikari, L. 2012. Xylans Inhibit Enzymatic Hydrolysis of Lignocellulosic Materials by Cellulases. Bioresource Technology. 121: 8-12.

Zhou, Z., Meng, Q. and Yu, Z. 2011. Effects of methanogenic inhibitors on methane production and abundances of methanogens and cellulolytic bacteria in in vitro ruminal cultures. Appl Environ Microbiol. 77: 2634-2639.

\section{How to cite this article:}

Prathvi V. Narsale, Sejal R. Patel and Pradeep Acharya. 2018. Role of Aspergillus flavus on Biodegradation of Lignocellulosic Waste Millet Straw and Optimization Parameters for Enzyme Hydrolysis and Ethanol Production under Solid State Fermentation. Int.J.Curr.Microbiol.App.Sci. 7(02): 429-445. doi: https://doi.org/10.20546/ijcmas.2018.702.055 